\title{
Sustainable Equity Crowdfunding Projects: Are They A Driving Force to Revitalise Italy After Global Socio-Economic Consequences of The COVID-19?
}

\author{
Maria Manganiello ${ }^{1 *}$,and Irina-Virginia Dragulanescu ${ }^{2}$ \\ ${ }^{1}$ University of Naples "Parthenope", Department of Economic and Legal Studies, Naples, Italy \\ ${ }^{2}$ University of Bucharest, Department of Economic and Administrative Sciences, Bucharest, Romania
}

\begin{abstract}
.
Research background: The outbreak of COVID-19 has disrupted and shaken all economic and financial sectors. In this scenario, crowdfunding has emerged as a new relevant financing mechanism alongside more traditional funding channels by attracting investors through an internetbased method of fundraising to support ventures. In recent years, many crowdfunding platforms, specialized in green projects rose, allowing startups to raise funds for their campaigns. The literature on the use of crowdfunding in the sustainable sector is quite limited.

Purpose of the article: We use a hand-collected dataset of 350 equity crowdfunding campaigns, gathered from the Italian platforms over the period January 2016-June 2020, to analyze the impact of COVID-19 outbreak on the success of green equity crowdfunding projects. We also test the greater attractiveness of the projects sustainability-oriented than other types of campaigns and if growth in the number of "green" projects is linked to the increase of local environmental performance.

Methods: We measure the probability of success of pitched projects, both in terms of the total amount raised and the number of investors. We run a negative-binomial-regression for the number of investors and a Tobitregression for the amount of capital raised.

Findings \& Value added: Coherently with our hypotheses, we find that COVID-19 has reduced the probability of success and that campaigns with a sustainability orientation are more likely to reach the funding target because investors give more importance to a sustainable future. Finally, our search provides that the leading countries in environmental performance have a positive effect on the green crowdfunding projects, by aspiring to move toward a sustainable future.
\end{abstract}

Keywords: Equity crowdfunding; Entrepreneurial finance; Signalling theory; Sustainability

JEL Classification: G24; G32; L26; M13; Q56

*Corresponding author: maria.manganiello@uniparthenope.it 


\section{Introduction}

Sustainability is becoming more important for companies across all industries. Many firms' executives consider a sustainability strategy necessary to be competitive today and to be it in the future. As the expectations on corporate responsibility increase, and as transparency becomes very prevalent, companies are recognizing the need to act on sustainability. Therefore, sustainable finance is a phenomenon increasingly of interest to investors who are more and more demanding reliable information on environmental, social, and governance issues.

Implementing sustainable development within financing systems makes it possible to direct capital and economic growth towards a type of development that is sustainable and that meets environmental, social, and economic criteria. Crowdfunding is a new means to finance sustainability-oriented projects, as an alternative to traditional financing channels for sourcing capital to support innovative, entrepreneurial ideas and ventures, like equity capital provided by professional investors and bank loans. Crowdfunding is an innovative and relatively new concept that connects investors to entrepreneurs. It is a new internet-based method of fundraising, based on the ability to pool money from potential investors that participate in the future cash flows of a firm [1].

Crowdfunding is presently growing very fast because it has the potential to foster innovation by offering new sources of capital thereby reduce the funding gap for innovative startups.

Crowdfunding can play an important role, for example, in the energy transition. This issue is demonstrated by the growth in Europe of energy cooperatives and participatory models for the development of investments in renewable energy [5, 14]. The use of crowdfunding in the energy sector is relatively recent, mainly to support investments in renewable energy projects from a mix of technologies. Crowdfunding has been used not only to raise capital for financing sustainable projects but also to support community energy initiatives and to foster the involvement of local actors in the development and deployment of distributed generation projects. Private sector developers have also used it crowdfunding to increase project visibility and local acceptance of energy projects.

Moreover, since crowdfunding platforms are strongly interconnected with social networks, they also represent an essential communication and marketing tools because they use digital marketing to reach the potential investors. Investors benefit from returns offered by project proponents in exchange for financial contributions, but they can also actively participate in online communities, sharing information, and providing suggestions.

Furthermore, the publication of a crowdfunding campaign on online platforms ensures full transparency and open communication on the projects to be funded and enable potential investors to engage themselves online with the project proponents, get involved, and monitor progress over time.

The literature on the use of crowdfunding in the energy sector is quite limited. Two academic papers review best practices, by mainly using case studies analysis [10, 14]. Other studies look at the determinants of the success of crowdfunding campaigns in the energy sector $[5,9,21]$.

Sustainability is a business approach to creating long-term value by taking into consideration how a given firm operates in the ecological, social, and economic environment. Sustainability is built on the assumption that developing such strategies foster company longevity, especially with the recent rise of awareness of the huge challenge firms got ahead, with climate change the ongoing global coronavirus pandemic in 2020.

The current COVID-19 global health pandemic that forced extraordinary measures such as social distancing and strict lockdowns in many countries is changing the world, bringing about an unprecedented crisis, and shaking up all sectors of the finance and real economy. It 
is also expected to cause changes in many of our certainties and practices by bringing back social and health considerations at the forefront of firms' investors' strategies and government agendas.

The long-term economic impact of COVID-19 remains unknown. Several studies [13] examine its impact across industries. Recent papers are investigating on how the previous relationships have changed during the COVID-19 outbreak $[7,8,12]$, its impact on the herding behavior [24] or the comovements across commodities, equities and economic policy uncertainty [19].

Given the global wide-scale of its impact, there are many reasons to suspect COVID-19 will change the dynamics of financial markets, both during the pandemic and in terms of changing thinking and practices in the future. Health uncertainties, as well as their increasing consequences for human life and activities, would also require stronger and faster actions to shape the pathways towards sustainability.

We decide to focus our research on the Italian context, for two reasons. First of all, Italy is the first country in Europe to have a specific discipline on equity crowdfunding (Law 221/2012 and CONSOB Regulation of 26 June 2013 n. 18592, as further amended in 2016 by the CONSOB decision n. 19520). Moreover, referring to the Italian context, equity crowdfunding has experienced exponential growth. Crowdfunding Buzz shows that 2018 was the year of the definitive consecration and diffusion of this alternative financial channel in which the equity crowdfunding platforms collected more than three times the amount gathered in 2017. In 2019 there was an increase of $82 \%$ compared to the previous year, for a total of 140 companies financed.

\subsection{Research hypotheses}

To date, no papers are investigating the impact of COVID-19 on the attractiveness of sustainability-oriented ventures in the Italian equity crowdfunding scenario. In this sense, we add to prior studies on this topic by providing new evidence on the quality signal of the greensustainable equity crowdfunding campaigns through a cross-platform analysis of the Italian context. We investigate all local platforms operating in Italy by analyzing a 5-year time horizon, i.e., from January 2016 to June 2020 . We consider this time-spanning because equity crowdfunding started its growth in 2016. We build up a hand-collected dataset of 414 equity crowdfunding campaigns, 213 of which are "green" projects pitched on equity crowdfunding platforms active in Italy, at the date of data collection (June 2020). The list of Italian authorized equity crowdfunding platforms is from the CONSOB registry.

In our opinion, the contagion from COVID-19 has modified not only the way of life and thinking but also the individuals' financial behavior. In detail, based on a cross-platform analysis of the Italian context, we analyse whether the COVID-19 outbreak has modified the key drivers of successful sustainable equity crowdfunding campaigns. Accordingly, our first hypothesis is the following:

H.1: COVID-19 outbreak has modified the key drivers of successful green equity crowdfunding campaigns by reducing the probability of success.

The investment decisions of different types of projects (or investors) are dominated by different logics. In detail, investors will select startups that are able to generate future profits in order to obtain high economic returns. According to previous literature $[15,20]$ and in line with these arguments, the economic paradigm and the market logic seems to be dominant. In reality, if we consider the different types of equity crowdfunding projects, there are differentiating sensibility related to the sustainability topic. By considering the sustainable projects, we believe that besides monetary returns, there are other motivations (i.e., the 
increase of environmental performance or the wellbeing at the local level) that affect the decision-making processes of potential investors.

We believe that the benefit of investing in a sustainability-oriented company and so, to contribute to project delivering some tangible benefit to the local community, has an added value, compared to the simple financial contribution.

As highlighted by the literature, crowdfunders are motivated by both financial and intrinsic objectives [2]. Social actions and environmental policy targets are crucial to generate tangible benefits in terms of income, jobs, and better services. In this sense, the willingness to support renewable energy production could increase. The equity crowdfunding of green projects may improve access to finance for climate action campaigns both in developed and in growing countries.

In line with these arguments, the level of confidence in policy measures could have a significant effect on investment decisions regarding renewable energy. These considerations lead to our second hypothesis:

H.2: Green projects are more likely to reach the target funding when the territories are best addressing the environmental challenges and in which they invest in policies and programs that lead to desirable sustainability outcomes.

\section{Methodology}

\subsection{Sample}

We analyze a sample of 414 equity crowdfunding campaigns launched between 2016 and June 2020 on the local platforms operating in Italy. The list of Italian authorized equity crowdfunding platforms is from the CONSOB registry. All the authorized equity crowdfunding platforms, according to the Italian regulation, are registered on this list. To identify sustainability-oriented equity crowdfunding campaigns, at first, we checked if the target to 'green' or 'sustainable' projects was explicitly mentioned. Then we carried out a text search by analyzing the description of the project analytically and in detail. This method yielded a sample of 213 campaigns. In June 2020, there were 21 platforms with active campaigns: Action Crowd, Back To Work 24, Cofyp, CrowdFundMe, Crowd Invest Italia, Ecomill, Extrafin, Forcrowd, Fundera, Idea Crowdfunding, Investi-re, Leonardo equity, Lita.co, Mamacrowd, Muum Lab, Next Equity, OpStart, Stars Up, The Best Equity, 200Crowd, We are starting.

\subsection{Variables}

To test our hypotheses, we gather information on equity crowdfunding campaigns from the platform's website. We run a set of empirical analyses with reference to two types of outcome variables as proxies of the campaign success. In line with previous studies $[1,6,23]$, we measure success by using 1) the number of investors (number of investors), and 2) the natural $\log$ of the amount raised at the end of the campaign (amount raised). As a robustness check, we run a regression with the success dummy as dependent variable to capture the degree to which a campaign was able to attract funds above the minimum target financing required.

We include a set of independent variables, in line with the crowdfunding literature. Our first hypothesis (H.1) aims to investigate the impact of COVID-19 on the success of 
sustainable equity crowdfunding projects, and so, the first key independent variable is a dummy, covid, equal to 1 if the project was launched during the outbreak, and 0 otherwise.

Prior research focusing on the determinants of equity crowdfunding successful campaigns points out that equity offered $[1,3,4,18,22,23]$, and social capital $[1,6,16,17$, 23 ] are the main uncontroversial key factors driving potential investors to finance equity crowdfunding projects. So, in order to take into account these features, we also include as our key independent variables the percentage of equity offered to investors (equity offered) reported in each offering, and the social capital of the founders (social capital), captured as the sum of Facebook likes, LinkedIn connections and Twitter followers [5, 11].

The COVID-19 pandemic has been able to change the investment decisions of individuals, by orienting them towards sustainable projects with high technological value. To this purpose, we include a dichotomous variable (tech) equal to 1 if the sustainable project is related to a high technological value, and 0 otherwise.

Crowdfunders could be motivated by both financial and intrinsic objectives [2]. In particular, environmental policy targets are crucial to generate tangible benefits in terms of income, jobs, and better services (such as access to clean energy). In this sense, the willingness to support renewable energy production could increase. To test our second hypothesis (H.2), we used the Environmental Performance Index (EPI) developed by Yale University (Yale Center for Environmental Law and Policy) and Columbia University (Center for International Earth Science Information Network) in collaboration with the World Economic Forum and the Joint Research Centre of the European Commission, as a method of quantifying and numerically marking the environmental performance of a state's policies.

The EPI offers a scorecard that highlights leaders and laggards in environmental performance and provides practical guidance for countries that aspire to move toward a sustainable future. The EPI is a composite indicator based on two main policy objectives: Environmental Health, which measures threats to human health, and Ecosystem Vitality, which measures natural resources and ecosystem services. The EPI includes 32 indicators grouped within 11 issue categories, and it is aggregated at each level using a simple weighted arithmetic average.

Moreover, entrepreneurs can include a detailed overview of the risks in the offering document for the purpose of reducing the problem of asymmetry information [1]. For this reason, we include financial info equal to 1 if financial information about the company is available on the platform and 0 otherwise.

In all our models, we also include a set of additional control variables to account for other factors, which are defined in line with previous studies on equity crowdfunding [1,22]. As regard, we control for the minimum of fundraising goal (i.e., the target amount of capital to be raised, target_capital), and the minimum amount required to invest (min investment). We use the founder's number of previous projects (founder experience) to capture the amount of human capital broadly, and so, the size of the top management team, reported on the "Team" page of each project [9].

Finally we capture other features of the campaign, by including the binary variable related to the presence of a video in the campaign pitch (video).

\section{Results}

According to prior studies [1,23], we run a standard method - a negative binomial regression for the natural logarithm of the number of investors that funded the project. Then, following [16], we run a Tobit regression for the amount of capital raised from a project at the end of the campaign. Finally, we run a logistic regression by using a dichotomous measure of campaign success (model 3), equal to 1 for campaigns reaching or exceeding their capital [1, $6,23]$ and zero otherwise. 
We also include both year fixed effects and platform fixed effects in order to capture the time of investments, to account for unobserved heterogeneity between the projects' attractiveness due to, e.g., varying degree of crowdfunding legitimacy over time or differing growth potentials between platforms.

Table 1 shows the results of the first econometric analysis, with dependent variables measuring crowdfunding campaign's success. Our first research question is to investigate if the key drivers that brought the crowd to finance a green equity crowdfunding campaign before COVID-19 are the same nowadays.

In order to test our first hypothesis (H.1) we build two interaction terms (equity offered_covid and social capital_covid) between the dummy covid and our two key variables that impact on the success of an equity crowdfunding campaign, that is equity offered $[1,18$, 23 , and social capital $[1,16,23]$. We do not include the value of the covid variable standing alone, since its effect would be not distinguishable from other factors that are country-specific and time-variant.

In Model 1 the campaign success is measured by using the natural log of the amount raised, in Model 2 we use as proxy of campaign's success the total number of investors at the end of the campaign, while in Model 3 our dependent variable is the dummy variable success. Our results show that our two key variables (equity offered and social capital), as well as all the coefficients of the interaction terms (the equity offered_covid and social capital_covid) are always significant at $10 \%$ confidence level or less.

In detail, social capital and its interaction with the dummy variable covid are strongly and positively associated with the campaign's success (always significant at the $1 \%$ confidence level), by confirming the relevant signalling role in the setting of equity crowdfunding. By conducting a more in-depth analysis of the coefficients, it can be noted that, during the lockdown, there has been an increase on the impact of social capital on the campaigns' success, in terms of the amount raised, the number of investors and the campaign's success. The equity offered, as well as its interaction term with covid (equity offered_covid) are negatively related to all our proxies of the success of the campaigns (at the confidence level ranging from $1 \%$ to $10 \%$ ). Hence, entrepreneurs can signal the quality of campaigns by offering a smaller percentage of equity and so, by retaining a higher percentage of its in their company. Entrepreneurs who are less dedicated to their company are likely to sell a higher amount of equity. Specifically, by comparing these two variables, our results show that there has been a decrease in the impact of equity offered by founders in this scenario characterized by a high level of the uncertainty triggered by COVID- 19 .

Referring to our control variables, we find that the number of visualization of the video uploaded on the project page has a positive impact on the equity crowdfunding campaigns. In detail, in all our model specifications, video is always significant at $1 \%$. This result is consistent with previous studies focusing on the relationship among the campaigns success probability and additional documents posted on the project page (i.e. videos, presentations, comments) useful for investors [4, 16, 22]. Moreover, the minimum investment ( $\mathrm{min}$ investment) has a negative impact both on the investor's decision to fund a project and on the amount raised, and it is also negatively related to the likelihood of success.

Moreover, also the technology firms (tech) affect positively the amount raised, the number of investors and the success (significant at 5\%). Finally, we find that sustainabilityoriented projects launched by founders with higher experience are positively associated with the likelihood of success. 
Table 1. Determinants of the amount raised, number of investors and success (H.1).

\begin{tabular}{|c|c|c|c|}
\hline VARIABLES & $\begin{array}{c}\text { (Model 1) } \\
\text { Amount Raised } \\
\end{array}$ & $\begin{array}{c}\text { (Model 2) } \\
\text { Number of investors }\end{array}$ & $\begin{array}{c}\text { (Model 3) } \\
\text { Success }\end{array}$ \\
\hline Equity offered & $\begin{array}{c}-0.678 * * * \\
(0.0219)\end{array}$ & $\begin{array}{c}-0.356 * * * \\
(0.0176)\end{array}$ & $\begin{array}{c}-0.453^{* *} \\
(0.198)\end{array}$ \\
\hline Equity offered covid & $\begin{array}{l}-0.346^{* *} \\
(0.0465)\end{array}$ & $\begin{array}{l}-0.176^{*} \\
(0.438)\end{array}$ & $\begin{array}{l}-0.343^{*} \\
(0.223)\end{array}$ \\
\hline Social capital & $\begin{array}{c}0.000386^{* * * *} \\
(0.0000213)\end{array}$ & $\begin{array}{c}0.000374 * * * \\
(0.0000429)\end{array}$ & $\begin{array}{l}0.0254 * * * \\
(0.00538)\end{array}$ \\
\hline Social capital covid & $\begin{array}{c}0.000642 * * * \\
(0.0000578)\end{array}$ & $\begin{array}{c}0.000544 * * * \\
(0.0000231)\end{array}$ & $\begin{array}{r}0.0512 * * * \\
(0.00844)\end{array}$ \\
\hline Min investment & $\begin{array}{l}-0.246^{*} \\
(0.0436)\end{array}$ & $\begin{array}{l}-0.235 * \\
(0.0523)\end{array}$ & $\begin{array}{l}-0.323 * \\
(0.198)\end{array}$ \\
\hline Financial info & $\begin{array}{c}0.324 \\
(0.566)\end{array}$ & $\begin{array}{c}0.132 \\
(0.163)\end{array}$ & $\begin{array}{l}0.596 * \\
(0.199)\end{array}$ \\
\hline Tech & $\begin{array}{l}0.255 * * \\
(0.0967)\end{array}$ & $\begin{array}{l}0.176^{* *} \\
(0.0243)\end{array}$ & $\begin{array}{l}0.367 * * \\
(0.256)\end{array}$ \\
\hline Founder experience & $\begin{array}{c}0.279 \\
(0.351)\end{array}$ & $\begin{array}{c}0.263 \\
(0.327)\end{array}$ & $\begin{array}{c}0.265^{* *} \\
(0.118)\end{array}$ \\
\hline Video & $\begin{array}{l}0.0643 * * * \\
(0.00326)\end{array}$ & $\begin{array}{l}0.0723 * * * \\
(0.00637)\end{array}$ & $\begin{array}{c}0.178 * * * \\
(0.0159)\end{array}$ \\
\hline Target capital & $\begin{array}{c}0.227 \\
(0.165)\end{array}$ & $\begin{array}{c}0.0365 \\
(0.0516)\end{array}$ & $\begin{array}{c}1.212 \\
(0.862)\end{array}$ \\
\hline Constant & $\begin{array}{c}4.683 * * * \\
(3.133)\end{array}$ & $\begin{array}{l}2.342 * * * \\
(0.577)\end{array}$ & $\begin{array}{l}15.21 * * \\
(10.34)\end{array}$ \\
\hline lnalpha & & $\begin{array}{c}-2.092 * * * \\
(0.134)\end{array}$ & \\
\hline Observations & 213 & 213 & 213 \\
\hline Year Fixed Effect & YES & YES & YES \\
\hline Platform Fixed Effect & YES & YES & YES \\
\hline Adj. R-squared & 0.3562 & 0.1674 & 0.5413 \\
\hline
\end{tabular}

In order to answer our second research hypothesis (H.2), and so, to test if the achievement of superior sustainability levels has a positive impact on the probability of the success of sustainability-oriented projects, we build the interaction term between the dummy covid and the environmental performance index, EPI (EPI_covid).

As reported in Table 2, findings show that $\overline{E P I}$ positively impacts the amount raised, the number of investors and the campaign's success at the $10 \%$ confidence level or less. Moreover, taking a look at the coefficient of the interaction term (EPI_covid), it appears that by considering the COVID-19 outbreak, backers are more prone to invest in a sustainabilityoriented project when countries are best addressing the environmental challenges, confirming that benefits to the local community are important to crowdfunding backers. As for the previous models, the signalling role played by equity offered and social capital is confermed, by pointing out, on one hand that outside investors may infer the quality of the campaigns by observing the percentage of equity offered, and on the other hand that founders have a greater chance of reaching the funding goal in a sustainable equity crowdfunding campaign if they "possess" more social capital. 
Table 2. Determinants of the amount raised, number of investors and success (H.2).

\begin{tabular}{|c|c|c|c|}
\hline VARIABLES & $\begin{array}{c}\text { (Model 1) } \\
\text { Amount Raised } \\
\end{array}$ & $\begin{array}{c}\text { (Model 2) } \\
\text { Number of investors }\end{array}$ & $\begin{array}{c}\text { (Model 3) } \\
\text { Success }\end{array}$ \\
\hline EPI & $\begin{array}{l}0.231 * \\
(0.098)\end{array}$ & $\begin{array}{c}0.127^{*} \\
(0.0184)\end{array}$ & $\begin{array}{l}0.234 * * \\
(0.104)\end{array}$ \\
\hline EPI covid & $\begin{array}{c}0.544 * * * \\
(0.132)\end{array}$ & $\begin{array}{l}0.248 * * * \\
(0.0307)\end{array}$ & $\begin{array}{c}0.465 * * * \\
(0.163)\end{array}$ \\
\hline Equity offered & $\begin{array}{c}-0.245^{* * *} \\
(0.0245)\end{array}$ & $\begin{array}{c}-0.186^{* * *} \\
(0.0221)\end{array}$ & $\begin{array}{c}-0.782 * * \\
(0.261)\end{array}$ \\
\hline Equity offered covid & $\begin{array}{l}-0.145^{* *} \\
(0.0430)\end{array}$ & $\begin{array}{l}-0.162 * * \\
(0.0265)\end{array}$ & $\begin{array}{l}-0.686^{*} \\
(0.258)\end{array}$ \\
\hline Social capital & $\begin{array}{c}0.000347 * * * \\
(0.0000239)\end{array}$ & $\begin{array}{c}0.000254 * * * \\
(0.0000378)\end{array}$ & $\begin{array}{l}0.0247 * * \\
(0.00117)\end{array}$ \\
\hline Social capital covid & $\begin{array}{c}0.000879 * * * \\
(0.0000418)\end{array}$ & $\begin{array}{c}0.000458 * * * \\
(0.0000105)\end{array}$ & $\begin{array}{l}0.0661 * * \\
(0.00248)\end{array}$ \\
\hline Min investment & $\begin{array}{l}-0.214 \\
(0.145)\end{array}$ & $\begin{array}{l}-0.114^{*} \\
(0.0223)\end{array}$ & $\begin{array}{l}-0.442 * \\
(0.133)\end{array}$ \\
\hline Financial info & $\begin{array}{l}0.246^{*} \\
(0.670)\end{array}$ & $\begin{array}{c}0.151 \\
(0.142)\end{array}$ & $\begin{array}{l}0.459 * \\
(0.133)\end{array}$ \\
\hline Tech & $\begin{array}{l}0.178 * * \\
(0.0667)\end{array}$ & $\begin{array}{l}0.144 * * \\
(0.0132)\end{array}$ & $\begin{array}{l}0.276^{* *} \\
(0.156)\end{array}$ \\
\hline Founder experience & $\begin{array}{c}0.734 \\
(0.0745)\end{array}$ & $\begin{array}{c}0.642 \\
(0.0489)\end{array}$ & $\begin{array}{l}0.688 * * \\
(0.245)\end{array}$ \\
\hline Video & $\begin{array}{l}0.0428 * * * \\
(0.00256)\end{array}$ & $\begin{array}{r}0.0536 * * * \\
(0.00643)\end{array}$ & $\begin{array}{c}0.144 * * * \\
(0.0169)\end{array}$ \\
\hline Target capital & $\begin{array}{c}0.244 \\
(0.150)\end{array}$ & $\begin{array}{c}0.0310 \\
(0.0231)\end{array}$ & $\begin{array}{l}1.132 * \\
(0.726)\end{array}$ \\
\hline Constant & $\begin{array}{c}4.345 * * * \\
(1.324)\end{array}$ & $\begin{array}{c}2.485 * * * \\
(0.786)\end{array}$ & $\begin{array}{c}16.14 * * \\
(12.62)\end{array}$ \\
\hline Inalpha & & $\begin{array}{c}-1.641^{* * *} \\
(0.218)\end{array}$ & \\
\hline Observations & 213 & 213 & 213 \\
\hline Year Fixed Effect & YES & YES & YES \\
\hline Platform Fixed Effect & YES & YES & YES \\
\hline Adj. R-squared & 0.3417 & 0.2754 & 0.4943 \\
\hline
\end{tabular}

\section{Conclusions}

The COVID-19 crisis has challenged public health systems and disrupted economic activity across the world. It has created unprecedented disruption for the global health and development community.

The implications of this global outbreak are evident everywhere, but the long-term consequences of the pandemic, and so, how it will reshape health and development institutions, occupations, financial behaviors, and priorities, are still difficult to imagine.

The study has a relevant impact on the sustainable energy generation because crowdfunding has the potential to represent an interesting source of capital, combining the opportunity of a profit with the desire to contribute to climate action initiatives. The ecological perspective has to inspire the policy transformation required for a sustainable future. 
We provide fresh evidence on the determinants of the Italian green crowdfunding campaigns by conducting a cross-platform analysis over the period 2016-June 2020 and on the effects of the local level of environmental performance on the successful campaigns. Our study confirms that crowdfunding is a viable alternative to financing green entrepreneurial projects.

By investigating the determinants of the funding success we find that the COVID-19 has modified the strength of the key drivers of successful green campaigns (H.1). In detail, if we compare the pre-COVID-19 period and the COVID-19 period, it is evident that there has been a stronger impact of proponents' social capital on the campaign's success, and a lower impact of the equity offered (by founders towards external investors) on successful projects. Regarding social capital, in this period of great uncertainty it can be observed that, during the lockdown, there has been an increase of its impact on the campaigns' success, in terms of amount raised, number of investors and successful projects.

The most surprising result concerns the equity offered. Although our results are consistent with prior studies on the topic, our findings show a strongly lower impact of the equity offered on the amount raised, on the number of investors and on the probability of campaigns' success during the COVID-19 pandemic. By considering the sustainable projects, this issue could be explain by highlighting that besides monetary returns, there are other motivations (i.e., the increase of environmental performance or the wellbeing at the local level) that affect the decision-making processes of potential investors. We also find that the larger is the increase in the environmental performance, the larger is the amount raised by green campaigns, more prone are the backers in investing in a sustainable project and the higher is the likelihood of the success.

Our analysis can also help policymakers to refine their policy agendas, facilitate communications with key stakeholders, maximize the return on environmental investments and contribute to strengthening the local awareness towards sustainability. In particular, these results could give important directives to managers' platform to understand the key sectors to focus on in the future in order to increase not only the probability of success of the campaigns but also to achieve greater profits and to sensitize potential entrepreneurs who intend to use crowdfunding to finance their startups.

\section{References}

1. Ahlers, G. K., Cumming, D., Günther, C., Schweizer, D. (2015). Signaling in equity crowdfunding. Entrepreneurship: Theory and Practice, 39(4), 955-980.

2. Allison, T. H., Davis, B. C., Short, J. C., Webb, J. W. (2015). Crowdfunding in a prosocial microlending environment: Examining the role of intrinsic versus extrinsic cues. Entrepreneurship Theory and Practice, 39(1), 53-73.

3. Barbi, M., Mattioli, S. (2019). Human capital, investor trust, and equity crowdfunding. Research in International Business and Finance, 49, 1-12.

4. Block, J., Hornuf, L., Moritz, A. (2018). Which updates during an equity crowdfunding campaign increase crowd participation?. Small Business Economics, 50(1), 3-27.

5. Bonzanini, D., Giudici, G., Patrucco, A. (2016). The Crowdfunding of Renewable Energy Projects In: Ramiah, V., Gregoriou, G. (eds.) Handbook of environmental and sustainable finance, Elsevier.

6. Colombo, M. G., Franzoni, C., Rossi Lamastra, C. (2015). Internal social capital and the attraction of early contributions in crowdfunding. Entrepreneurship Theory and Practice, 39(1), 75-100. 
7. Conlon, T., Corbet, S., McGee, R. J. (2020). Are Cryptocurrencies a Safe Haven for Equity Markets? An International Perspective from the COVID-19 Pandemic. Research in International Business and Finance, 54, Article Number 101248 .

8. Conlon, T., McGee, R. J. (2020). Safe Haven or Risky Hazard? Bitcoin during the COVID-19 Bear Market. Finance Research Letters, 35, Article Number 101607.

9. Cumming, D. J., Meoli, M., Vismara, S. (2019). Investors' choice between cash and voting rights: evidence from dual-class equity crowdfunding. Research Policy, 48(8), 103740.

10. De Broeck, W. (2018). Crowdfunding platforms for renewable energy investments: an overview of best practices in the EU. International Journal of Sustainable Energy Planning and Management, 15, 3-10.

11. Giudici, G., Guerini, M., Rossi-Lamastra, C. (2018). Reward-based crowdfunding of entrepreneurial projects: the effect of local altruism and localized social capital on proponents' success. Small Business Economics, 50(2), 307-324.

12. Goodell, J.W., Goutte, S. (2020). Co-Movement of COVID-19 and Bitcoin: Evidence from Wavelet Coherence Analysis. Retrieved from:

https://papers.ssrn.com/sol3/papers.cfm?abstract_id=3597144.

13. Goodell, J. W., Huynh, T. L. D. (2020). Did Congress trade ahead? Considering the reaction of US industries to COVID-19. Finance Research Letters, 36, Article Number 101578.

14. Lam, P. T. I., Law, A. O. K. (2016). Crowdfunding for renewable and sustainable energy projects: An exploratory case study approach. Renewable and Sustainable Energy Reviews, 60, 11-20.

15. Pahnke, J., Strasser, S., Vieide, F.M. (2015). Responsibility effects in decision making under risk. Journal of Risk and Uncertainty, 51(2), 125-146.

16. Piva, E., Rossi-Lamastra, C. (2018). Human capital signals and entrepreneurs' success in equity crowdfunding. Small Business Economics, 51(3), 667-686.

17. Polzin, F., Sanders, M., Stavlöt, U. (2018). Do investors and entrepreneurs match?Evidence from The Netherlands and Sweden. Technological Forecasting and Social Change, 127, 112-126.

18. Ralcheva, A., Roosenboom, P. (2019). Forecasting success in equity crowdfunding. Small Business Economics, 55(1), 39-56.

19. Sharif, A., Aloui, C., Yarovaya, L. (2020). COVID-19 Pandemic, Oil Prices, Stock Market, Geopolitical Risk and Policy Uncertainty Nexus in the US Economy: Fresh Evidence from the Wavelet-Based Approach. International Review of Financial Analysis, 70, Article Number 101496.

20. Thornton, P.H., Ocasio, W., Lounsbury, M. (2012). The Institutional Logics Perspective: A New Approach to Culture, Structure, and Process. UK: Oxford University Press.

21. Vismara, S., (2019). Sustainability in equity crowdfunding. Technological Forecasting and Social Change, 141, 98-106.

22. Vismara, S. (2018). Information cascades among investors in equity crowdfunding. Entrepreneurship Theory and Practice, 42(3), 467-497.

23. Vismara, S. (2016). Equity retention and social network theory in equity crowdfunding. Small Business Economics, 46(4), 579-590.

24. Yarovaya, L., Matkovskyy, R., Jalan, A. (2020). The Effects of a 'Black Swan' Event (COVID-19) on Herding Behavior in Cryptocurrency Markets: Evidence from Cryptocurrency USD, EUR, JPY and KRW Markets. Retrieved from: https://papers.ssrn.com/sol3/papers.cfm?abstract_id=3586511. 